Article

\title{
Combined Effects of Mulch and Tillage on Soil Hydrothermal Conditions under Drip Irrigation in Hetao Irrigation District, China
}

\author{
Zhijuan Qi ${ }^{1,2}$, Tibin Zhang ${ }^{1}$, Lifeng Zhou ${ }^{3}$, Hao Feng ${ }^{1,3, *}$, Ying Zhao ${ }^{1,4,5, *}$ and Bingcheng $\mathrm{Si}^{3,5}$ \\ 1 State Key Laboratory of Soil Erosion and Dryland Farming on the Loess Plateau, Institute of Soil and \\ Water Conservation, Chinese Academy of Sciences and Ministry of Water Resources, Yangling 712100, \\ China; qizhijuansoil@gmail.com (Z.Q.); zhangtb@nwafu.edu.cn (T.Z.) \\ 2 University of Chinese Academy of Sciences, Beijing 100049, China \\ 3 College of Water Resources and Architectural Engineering, Northwest A\&F University, Yangling 712100, \\ China; zhoulfsoil@gmail.com (L.Z.); Bing.Si@usask.ca (B.S.) \\ 4 Key Laboratory of Plant Nutrition and the Agri-Environment in Northwest China, Ministry of Agriculture, \\ Northwest A\&F University, Yangling 712100, China \\ 5 Department of Soil Science, University of Saskatchewan, Saskatoon, SK S7N 5A8, Canada \\ * Correspondence: nercwsi@vip.sina.com (H.F.); zhaosoils@gmail.com (Y.Z.); \\ Tel.: +86-29-8701-2210 (H.F.); +86-29-8708-0055 (Y.Z.)
}

Academic Editor: Timothy R. Green

Received: 28 August 2016; Accepted: 26 October 2016; Published: 3 November 2016

\begin{abstract}
Soil hydrothermal condition is one of the most important factors affecting crop growth in arid regions. This study aimed to investigate the effect of mulching and tillage on moisture and temperature variations in soil under drip irrigation in the arid Hetao Irrigation District, northwest China. Four treatments were included: (1) alternating ridges $(40 \mathrm{~cm}$ wide and $20 \mathrm{~cm}$ high) and furrows ( $40 \mathrm{~cm}$ wide) with plots fully mulched with plastic film (RFM); (2) alternating ridges $(40 \mathrm{~cm}$ wide and $20 \mathrm{~cm}$ high) and furrows (40 $\mathrm{cm}$ wide) with partial film mulch (only the plant rows mulched) (RPM); (3) flat tillage with plots fully mulched with plastic film (FFM); and (4) flat tillage with partial film mulch (only the plant rows mulched) (FPM). The ridge tillage and plastic film increased soil temperature and significantly conserved soil water, and thus increased the maize yield and water use efficiency (WUE). The RFM treatment had a greater effect than the RPM, FFM, and FPM treatments on the soil moisture and water storage over $0-70 \mathrm{~cm}$ in depth during the entire growing period in 2014 and 2015, indicating that full transparent plastic film mulch increased soil water status and promoted deep water percolation, and ridge tillage further enhanced water redistribution to deep soils. Furthermore, RFM proportionally increased soil temperature by $0.36{ }^{\circ} \mathrm{C}$, $1.49^{\circ} \mathrm{C}$, and $1.27^{\circ} \mathrm{C}$ above the temperatures under RPM, FPM, and FFM, respectively, in 2014 and by $1.19^{\circ} \mathrm{C}, 1.62^{\circ} \mathrm{C}$, and $0.35^{\circ} \mathrm{C}$, respectively, in 2015 . During the drought year of 2014, tillage influenced temperature more than mulching; however, mulching played a more important role in preserving thermal conditions than tillage during the humid year of 2015. Consequently, RFM increased the maize yield and WUE significantly. We conclude that a combined system of full plastic film mulch and ridge tillage creates beneficial soil hydrothermal conditions under drip irrigation and thus promotes the growth and performance of field crops.
\end{abstract}

Keywords: mulch; drip irrigation; ridge tillage; soil temperature; soil moisture

\section{Introduction}

The Hetao Irrigation District, Inner Mongolia, is the largest designed irrigation area and a major grain and oil seed production region in China. Maize is widely grown in this district, which 
has abundant light and heat. However, climatic conditions can be harsh, including seasonal water shortages and significant diurnal temperature variations in summer [1-3]. Crop production in this region is further threatened by soil erosion, drought, and strong evaporation [4-6]. Therefore, it is important to retain the limited precipitation and reduce both non-beneficial evaporation and diurnal temperature variation in shallow soil layers via measures such as conservation tillage, mulching and water-saving irrigation methods.

Ridge tillage, as a conservation tillage method, has been widely adopted worldwide. Obviously, due to the micro-topographic effects, the ridge may cause lateral water flow and thus increase the soil moisture of the furrow. In addition, ridge tillage can change soil structure and improve macropore development, thus improving the route for vertical and horizontal water and solute flow into the soil profile before saturation, resulting in increased infiltration and reducing soil erosion and the need for supplementary watering. Ridge tillage can enhance daily soil temperature by as much as $2{ }^{\circ} \mathrm{C}$ above the temperature on a level surface due to increased sunlight in the harvesting area [5]. Zhang et al. [7] reported that ridge tillage can significantly improve maize production by enhancing soil organic matter and soil water availability. Yasushi et al. [8] found that soil macropores could increase plant biomass two-fold and significantly increase soil carbon content. Previous studies have suggested that ridge tillage could improve sunlight reception, soil quality, soil water environment and help to control soil erosion [9-11].

Plastic film mulching, a widely applied water management practice in arid and semiarid areas, effectively controls soil temperature and decreases evaporation, and thus increases water utilization [12-14]. Studies have shown that plastic film mulch can reduce overheating of topsoil by reflecting solar radiation in daytime, and reduce soil heat loss owing to its light transmission and reduction of evaporation at night $[15,16]$. Gan et al. [17] reported that crop production and water use efficiency (WUE) are significantly enhanced by plastic film mulch because the film improves soil water storage and promotes more uniform distribution of water in the soil. Thus, crops could grow under appropriate soil hydrothermal conditions - as heat transport always accompanies water flow-and modified soil temperature contributes to the decomposition of fertilizer and accumulation of organic materials [18-20].

Drip irrigation is one of the most efficient water-saving irrigation methods under plastic mulch because it not only permits precise control of irrigation quantity but also increases irrigation WUE by reducing evaporation and increasing infiltration [21]. However, soil moisture is not evenly distributed under drip irrigation, and thus root system and plant development are influenced. Drip irrigation is normally combined with conservation tillage or mulching in fields, which combine to promote crop growth while maintaining the water-saving advantage of drip irrigation. Chen et al. [22] found that plastic film mulched ridge tillage increased precipitation infiltration throughout the entire growth period. In this system, the plastic film on the ridges is beneficial as it promotes soil thermal transmission and water flow into the furrows [23]. In addition, it is beneficial in reducing water loss by evaporation during the early growing stage and also in maintaining soil fertility [24]. Burt and Isbell [25] found that mulched drip irrigation was able to maintain moderate soil matric potential, help control weeds and promote crop production. Selim et al. [26] also indicated that the problem associated with salinity could be overcome effectively under mulched drip irrigation because of controlled leaching and that plastic film mulch has significant effects on soil water, soil thermal and salinity distribution.

Soil temperature is interrelated and interacts with soil moisture through evaporation and plant transpiration. Moderate soil hydrothermal conditions are beneficial in promoting the activity of soil microorganisms and soil nutrient cycling, further increasing crop production and WUE [27]. Plastic film combined with straw mulch could adjust soil temperature (depending on atmospheric temperature) and invariably enhance the grain yield and WUE [22]. Wang et al. [28] found that plastic mulch combined with ridge-furrow tillage could increase soil temperature and soil moisture and also the maize yield in more hydrothermally limited conditions. Zhou et al. [14] reported that double ridges and furrow mulched with plastic film treatment could increase precipitation retention and receive 
more solar energy resulting in enhancing soil temperature. Although there are a few studies on soil hydrothermal conditions investigated through ridge tillage mulched with plastic film, the combined effects of different tillage mulched with full and partial plastic film with drip irrigation are rarely studied. We hypothesized that the use of the plastic film mulching and tillage method under drip irrigation would increase soil temperature and conserve soil moisture, but would not reduce the crop yield or WUE. Our objectives are: (1) to investigate the effects of combined ridge tillage and mulching with drip irrigation on soil hydrothermal regime; and (2) to understand the mechanisms in this system and thus improve the efficiency of the resources. The results could provide a theoretical basis for improving soil hydrothermal conditions in arid areas and thus enhance crop productivity and quality.

\section{Materials and Methods}

\subsection{Experimental Site}

The field experiments were conducted in 2014 and 2015 at the Shuguang Experimental Station $\left(40^{\circ} 46^{\prime} \mathrm{N}, 107^{\circ} 24^{\prime} \mathrm{E}\right)$, located in the west of the Hetao Irrigation District in Inner Mongolia, China. This area has a semiarid continental climate with an average annual precipitation of $180 \mathrm{~mm}$ with ranges from 139 to $222 \mathrm{~mm}$, average annual temperature of $6.9^{\circ} \mathrm{C}$, and mean potential evaporation of 2200-2400 mm. The average air temperature and evaporation in 2014 was slightly higher than in 2015, while average relative humidity in 2015 was higher than in 2014 in all the growth stages (Figure 1). The soil in the study area begins to freeze by the middle of November and does not thaw completely until late April [4]. According to the protocol of the soil agro-chemistry analysis [13], the 1:5 soil-water extract for each soil sample was prepared; the initial soil salt content was determined using a conductivity meter (DDS-11A, REX, Shanghai, China); the cations were determined by the atomic absorption spectrophotometer (WFX-120, BRAIC, Beijing, China); the anions were determined by the titration method. The soil properties of the experimental field are shown in Tables 1 and 2.

Table 1. Soil properties in the $0-70-\mathrm{cm}$ soil layer of the experimental field.

\begin{tabular}{|c|c|c|c|c|c|c|c|}
\hline \multirow{2}{*}{$\begin{array}{l}\text { Depth of Soil } \\
\text { Layer (cm) }\end{array}$} & \multicolumn{3}{|c|}{ Particles Size Distribution (\%) } & \multirow{2}{*}{$\begin{array}{l}\text { Bulk Density } \\
\left(\mathrm{g} / \mathrm{cm}^{3}\right)\end{array}$} & \multirow{2}{*}{$\begin{array}{c}\text { Organic Matter } \\
(\mathrm{g} / \mathrm{kg})\end{array}$} & \multirow{2}{*}{$\begin{array}{c}\mathrm{EC}_{1: 5} \\
(\mathrm{dS} / \mathrm{m})\end{array}$} & \multirow{2}{*}{$\mathrm{pH}$} \\
\hline & Sand & Silt & Clay & & & & \\
\hline $0-20$ & 5.57 & 23.77 & 70.65 & 1.44 & 7.26 & 0.46 & 8.61 \\
\hline $20-40$ & 5.11 & 23.18 & 71.71 & 1.43 & 8.11 & 0.30 & 8.67 \\
\hline $40-70$ & 49.73 & 8.37 & 41.90 & 1.45 & 6.27 & 0.24 & 8.90 \\
\hline
\end{tabular}

Table 2. Solution chemistry of soil pore water and groundwater.

\begin{tabular}{|c|c|c|c|c|c|c|c|c|}
\hline \multirow{2}{*}{$\begin{array}{l}\text { Depth of Soil } \\
\text { Layer (cm) }\end{array}$} & \multicolumn{6}{|c|}{ Concentration $(\mathrm{mg} / \mathrm{L})$} & \multirow{2}{*}{$\mathrm{pH}$} & \multirow{2}{*}{$\mathrm{EC}(\mathrm{dS} / \mathrm{m})$} \\
\hline & $\mathrm{HCO}_{3}^{-}$ & $\mathrm{Cl}^{-}$ & $\mathrm{SO}_{4}{ }^{2-}$ & $\mathrm{Ca}^{2+}$ & $\mathrm{Mg}^{2+}$ & $\mathrm{Na}^{+}+\mathrm{K}^{+}$ & & \\
\hline $0-10$ & 81.21 & 398.81 & 170.47 & 320.80 & 57.00 & 39.15 & 8.15 & 1.52 \\
\hline $10-20$ & 75.49 & 504.06 & 199.20 & 401.11 & 50.59 & 37.02 & 8.18 & 1.63 \\
\hline $20-30$ & 76.64 & 426.51 & 193.80 & 55.35 & 42.66 & 40.41 & 8.37 & 0.90 \\
\hline $30-40$ & 83.12 & 515.14 & 186.60 & 41.47 & 25.79 & 46.41 & 8.52 & 0.77 \\
\hline $40-70$ & 105.61 & 448.67 & 177.93 & 24.81 & 17.86 & 52.60 & 8.68 & 0.56 \\
\hline Groundwater & 335.60 & 159.50 & 312.20 & 60.10 & 91.10 & 150.00 & 7.69 & 1.76 \\
\hline
\end{tabular}



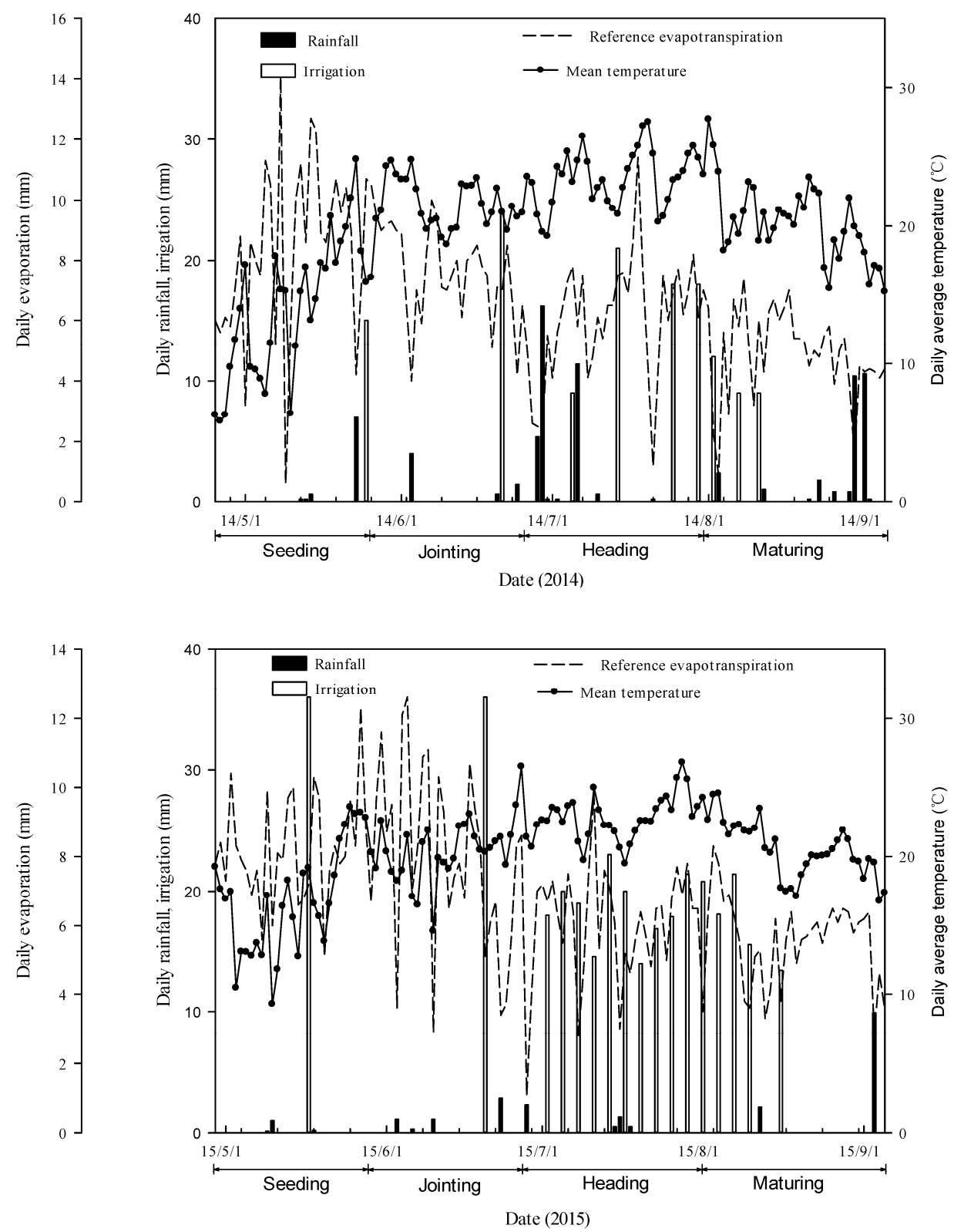

Figure 1. Rainfall, evaporation, irrigation, and temperature during crop growth stages in 2014 and 2015.

\subsection{Experimental Design}

The experiment treatments were all based on drip irrigation and included two plastic film mulch treatments (full vs. partial mulch) and two tillage treatments (ridge vs. flat tillage), respectively. There were four combined systems: (1) alternating ridges $(40 \mathrm{~cm}$ wide and $20 \mathrm{~cm}$ high) and furrows (40 cm wide) with plots fully mulched with plastic film (RFM); (2) alternating ridges (40 cm wide and $20 \mathrm{~cm}$ high) and furrows (40 cm wide) with partial film mulch (only the plant rows mulched) (RPM); (3) flat tillage with plots fully mulched with plastic film (FFM); and (4) flat tillage with partial film mulch (only the plant rows mulched) (FPM). The cropping pattern is shown in Figure 2. Each treatment was replicated four times and each experimental plot was approximately $4 \mathrm{~m} \times 12 \mathrm{~m}$ in a completely randomized block design (Figure 3). The plastic film in all treatments was transparent polyethylene and $0.008 \mathrm{~mm}$ thick. The experimental crop was maize (cultivar Xi-meng 6, Xi-meng Seed Ltd., Inner Mongolia, China) with wide-narrow row sowing and the whole growing season required approximately 120 days. The drip tapes were laid out in the middle of narrow rows and used 
to deliver water with flow rates of $1.38 \mathrm{~L} / \mathrm{h}$ in 2014 and $2.7 \mathrm{~L} / \mathrm{h}$ in 2015 . The drip tape spacing and emitter spacing were $100 \mathrm{~cm}$ and $30 \mathrm{~cm}$, respectively. Two rows of maize were planted on both sides of the drip tape with a $20-\mathrm{cm}$ space between two rows.

Ridge tillage and transparent plastic mulches were applied in the middle of April in 2014 and 2015. Maize was sown on 24 April in 2014 and on 28 April in 2015 and was harvested on 4 September in 2014 and 5 September in 2015, respectively. Maize was harvested at around 20\% moisture in 2014 and 2015. Urea plus $\left(\mathrm{NH}_{4}\right)_{2} \mathrm{HPO}_{4}$ was used as the base fertilizer and urea, phosphate fertilizer and $\mathrm{KNO}_{3}$ as the topdressing applied in different amounts and growth stages. The experimental period was from late April to early September in 2014 and 2015. After harvesting, transparent plastic mulches were removed from all plots. In addition, the field was ploughed and supplied by flood irrigation for planting in spring of the following year.

(RFM)

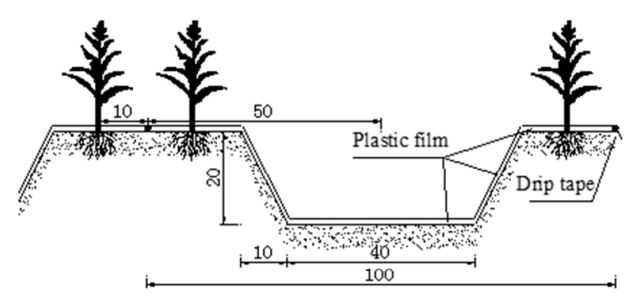

(FFM)

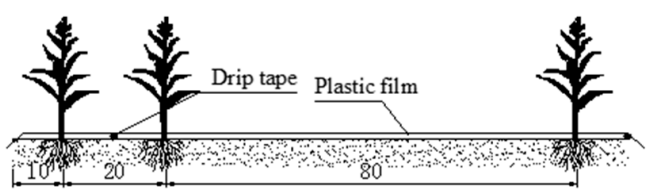

(RPM)

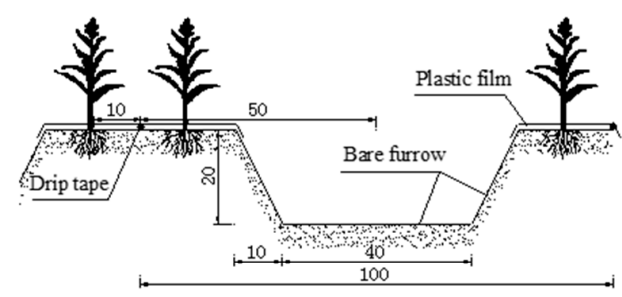

(FPM)

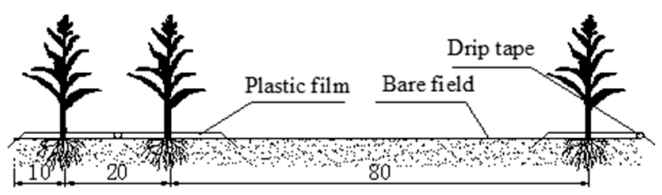

Figure 2. Schematic showing the cropping pattern.

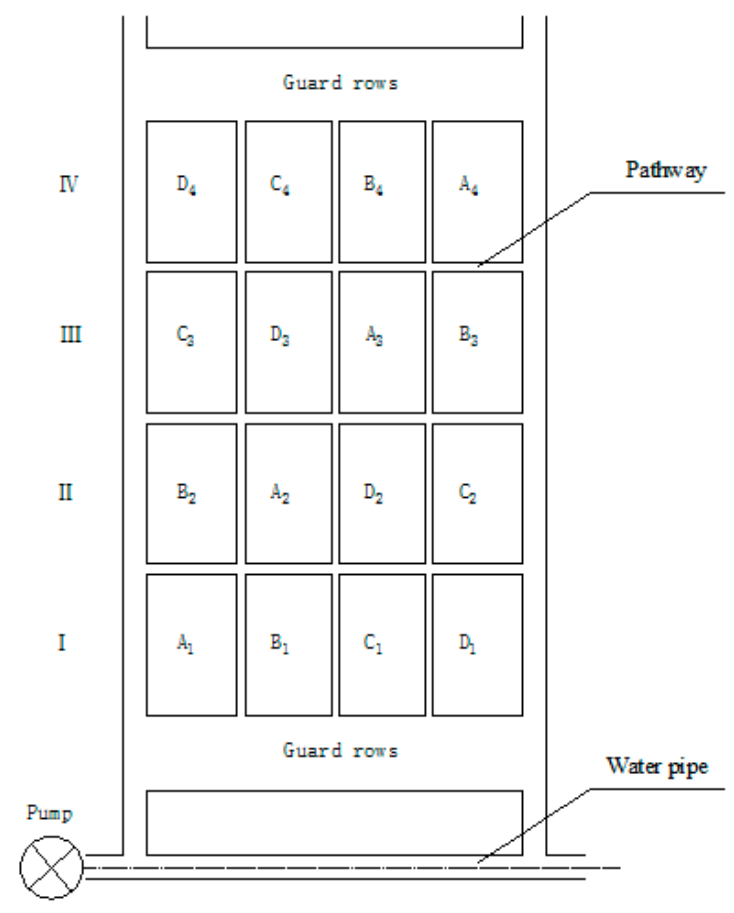

Figure 3. Layout of field plot. 


\subsection{Measurements}

$\mathrm{ECH}_{2} \mathrm{O}-5 \mathrm{TE}$ sensors (Decagon Devices, Inc., Pullman, WA, USA) were installed in experimental plots (15 sensors in total per plot) beneath the emitter at the soil depths of 10, 30, 55, 85 and $110 \mathrm{~cm}$ at three locations to record profiled soil moisture and temperature of 20-, 40-, 70-, 100- and 120-cm layers, which was used to evaluate the effect of different treatments on soil water and thermal regime during the growth period. Data were collected hourly by automatic data loggers.

In order to explore thermal effects at different positions under film, temperature sensor probes (RH-PT1000A, RUNHU Ltd., Shanghai, China) was used below the soil surface. The data were recorded every $1 \mathrm{~h}$. In the FFM treatment, probes were installed at $0 \mathrm{~cm}$ (center-position under film), $20 \mathrm{~cm}$ (inter-position under film) and $50 \mathrm{~cm}$ (edge-position under film) from the emitter in a horizontal position within the film. Accumulated temperature was calculated as the sum of the daily average soil temperature (above $10^{\circ} \mathrm{C}$ ) in 0-20-cm layers.

The total water consumption $(E T=$ evapotranspiration, $\mathrm{mm}$ ) can be calculated by the formula:

$$
E T=\Delta W+P+I+G-R-F
$$

where $\Delta W$ is the difference in soil moisture in the $0-120-\mathrm{cm}$ layer between the beginning and end of experimental period, $P$ and $I$ are precipitation and irrigation respectively, $G$ is groundwater imbibition to the root system (calculated following the method described in Sepaskhah et al. [29]), $R$ is the surface runoff (there was no surface runoff, as the plot was flat), $F$ is drainage (assumed to be zero, because drip irrigation and precipitation are too low to cause drainage below $2 \mathrm{~m}$ ).

The water use efficiency $\left(W U E, \mathrm{~kg} \cdot \mathrm{ha}^{-1} \cdot \mathrm{mm}^{-1}\right)$ was calculated as the grain yield $\left(Y, \mathrm{~kg} \cdot \mathrm{ha}^{-1}\right)$ divided by ET:

$$
W U E=Y / E T
$$

During the different growth stages, samples of aboveground biomass were collected from 1-m sections of rows of each plot. The leaf area index (LAI) of maize was determined using the same samples as determining aboveground biomass. The leaf area of the whole plant was measured and the LAI (leaf area/ground area, $\mathrm{m}^{2} / \mathrm{m}^{2}$ ) was calculated. The individual leaf area was determined by leaf length $\times$ leaf width $\times$ coefficient. Leaf size was measured with a ruler. The coefficient value was 0.7 determined using the same method as Gao et al. [30]. Then the maize plants were separated into leaves, stems and ears. Immediately after harvesting, all samples were dried in an oven at $85^{\circ} \mathrm{C}$ for $48 \mathrm{~h}$ to determine aboveground biomass.

When mature, maize cobs were collected to determine the grain yield and its component factors from a sampling area of $3 \mathrm{~m}$ row length $\times 0.2 \mathrm{~m}$ width (two rows) in each plot center. The number of rows and grains per ear were counted and the grain yield of maize was measured after solar drying keeping grain moisture content around $13 \%$.

\subsection{Statistical Analyses}

Two-way analysis of variance (ANOVA) was conducted to evaluate the effects of treatments on the measured parameters. Statistical analyses were performed using R (version 3.1.0, R Foundation for Statistical Computing, Vienna, Austria) and presented as the mean of replicates \pm standard error (S.E). Significance between treatments was checked at $p \leq 0.05$.

\section{Results}

\subsection{Soil Moisture}

During the 2014 and 2015 season, soil water content showed a similar interannual trend and fluctuated with irrigation, precipitation and temperature (Figure 4a). Due to limited precipitation, soil moisture was mainly influenced by irrigation. Soil moisture in all treatments increased from $0-\mathrm{cm}$ to $40-\mathrm{cm}$ soil depth and then decreased from $40-\mathrm{cm}$ to $70-\mathrm{cm}$ soil depth during seeding and 
heading stages. Figure 4a also reveals that RFM had higher soil moisture than RPM, FFM and FPM in the $0-20-\mathrm{cm}$ layer throughout all growing stages. With increasing precipitation and irrigation, the soil water content in RFM and FFM was much higher than in RPM and FPM in the 70-cm layer, suggesting a greater infiltration associated with reduced evaporation in full film mulching. During the heading and maturing stage, soil moisture in RFM in the 40-cm layer fell below FFM, and the same was observed for FPM vs. RPM. The soil water content in full film mulched treatment was lower than in partial film mulched treatment in the 40-70-cm layer. This indicates that although ET for the full film mulched treatment was more reduced than that of the partial film mulched treatment, the full film mulch did not increase the soil water content, but rather promoted vigorous plant growth resulting in a higher plant transpiration rate and overall more soil water loss.

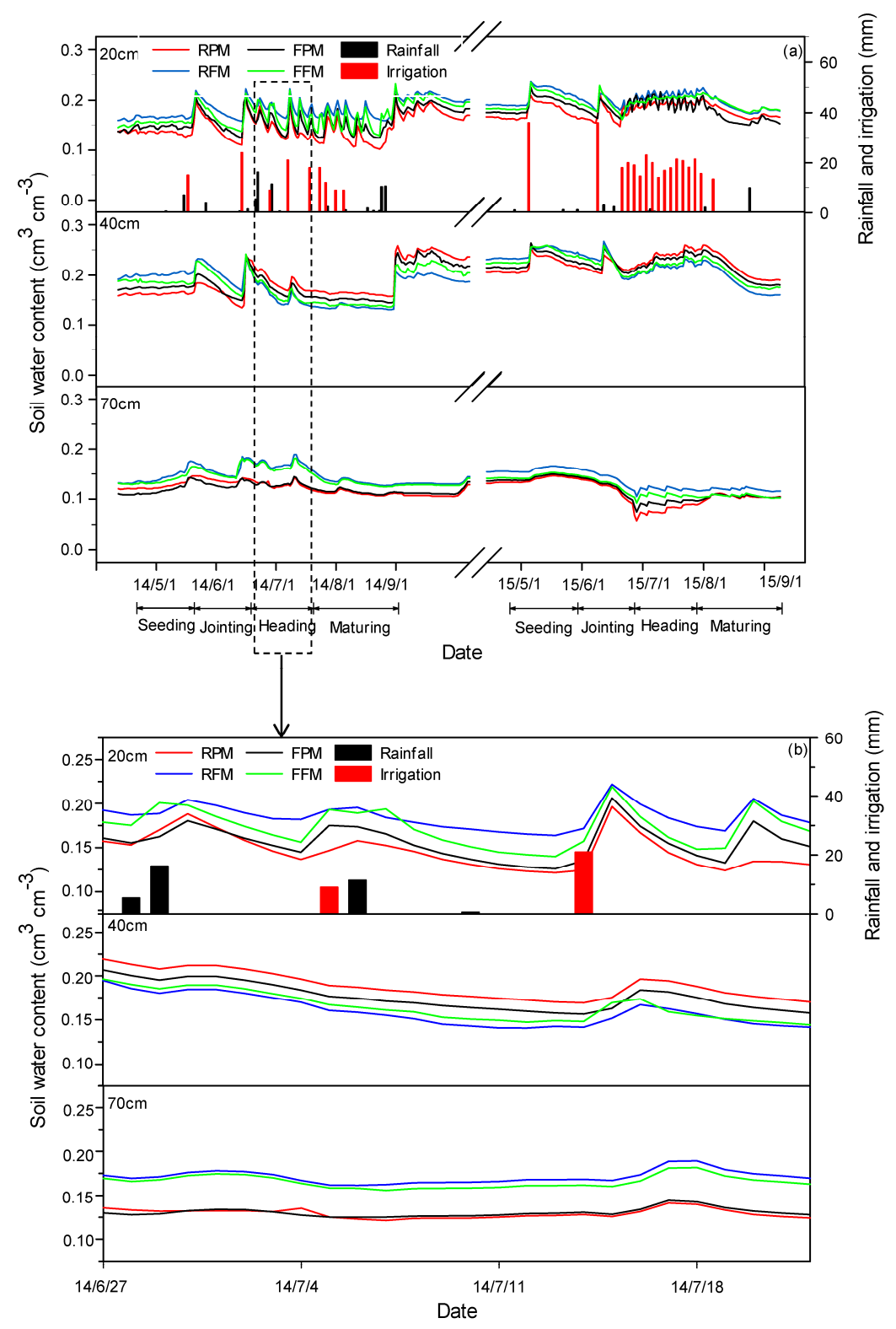

Figure 4. Soil water content in the top 70-cm of the soil in different treatments (a) during the growth period in 2014 and 2015 and (b) during the heading stage in 2014.

During the seeding stage, soil water content of the RFM treatment was higher than RPM, FFM and FPM treatments and increased by an average of $21.3 \%, 7.1 \%$ and $13.8 \%$ in 2014 and $14.4 \%, 3.6 \%$ and 
$8.2 \%$ in 2015 in the $0-20-\mathrm{cm}$ layer, respectively. At the jointing stage, because of limited maize water consumption and quantity of solar radiation, soil water content in the $0-40-\mathrm{cm}$ layer was highest in RFM and increased up to $21.9 \%, 7.1 \%$ and $14.7 \%$ in 2014 , and $14.1 \%, 2.7 \%$ and $7.8 \%$ in 2015 over that in RPM, FFM and FPM treatments, respectively. During the heading stage and maturing stage, with the increasing maize water consumption, the vertical distribution of soil water content in RFM and FFM was decreased more than in RPM and FPM. In 2014, the soil moisture fluctuated more widely because irrigation was less frequent than in the drier 2015 season. Because of the more frequent irrigation in 2015, the soil moisture differences among all treatments in the top $40 \mathrm{~cm}$ of the soil in 2015 were smaller than those observed in 2014. Variation in soil moisture was more pronounced during the period of greatest water demand for maize (Figure $4 \mathrm{~b}$ ). In all four treatments, the soil water content showed a similar overall trend, with the most distinct differences in shallow layers $(0-40-\mathrm{cm})$ compared with deep layers $(40-70-\mathrm{cm})$.

\subsection{Soil Water Storage}

Figure 5 illustrates the changes of soil water storage in $0-70-\mathrm{cm}$ layers during the growth period in 2014 and 2015. In accordance with soil moisture variation, the range of soil water storage in the main root region $(0-40-\mathrm{cm})$ is greater than in the deeper layer $(40-70-\mathrm{cm})$. In addition, there were obvious differences in soil water storage among these four treatments at the same stage and the highest and lowest values were recorded in the seeding and maturing stages, respectively. It was notable that soil water storage in the 20-40-cm layer in RFM and FFM was lower than RPM and FPM during the heading and maturing stages. The fully mulched plots (RFM and FFM) generally had the largest soil water storage in the $0-70 \mathrm{~cm}$ soil profile.
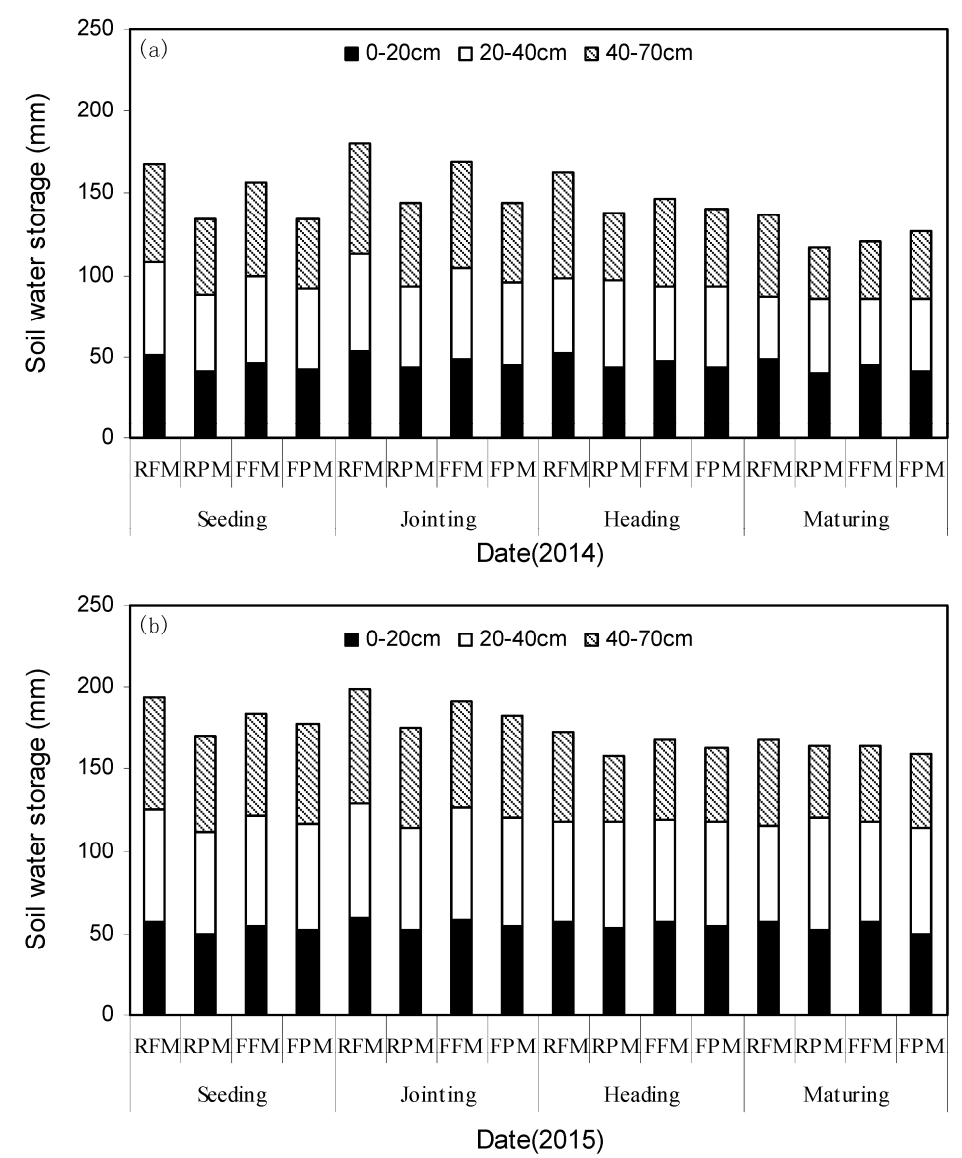

Figure 5. Soil water storage of the 0-70-cm layer in different treatments during the growth period in 2014 (a) and 2015 (b). 


\subsection{Soil Temperature}

During the entire monitoring period, RFM showed more discernible thermal conservative effects than the other treatments (Figure 6a). Overall, average soil temperature in the 0-70-cm layer in RFM was $0.36{ }^{\circ} \mathrm{C}, 1.49^{\circ} \mathrm{C}$, and $1.27^{\circ} \mathrm{C}$ higher in 2014 , and $1.19^{\circ} \mathrm{C}, 1.62{ }^{\circ} \mathrm{C}$, and $0.35^{\circ} \mathrm{C}$ higher in 2015 than RPM, FPM and FFM, respectively. The soil temperature in the ridge tillage treatments was higher than in the flat tillage plots in 2014, while the soil temperature of the full film mulching treatments was higher than with partial film mulch plots in 2015.

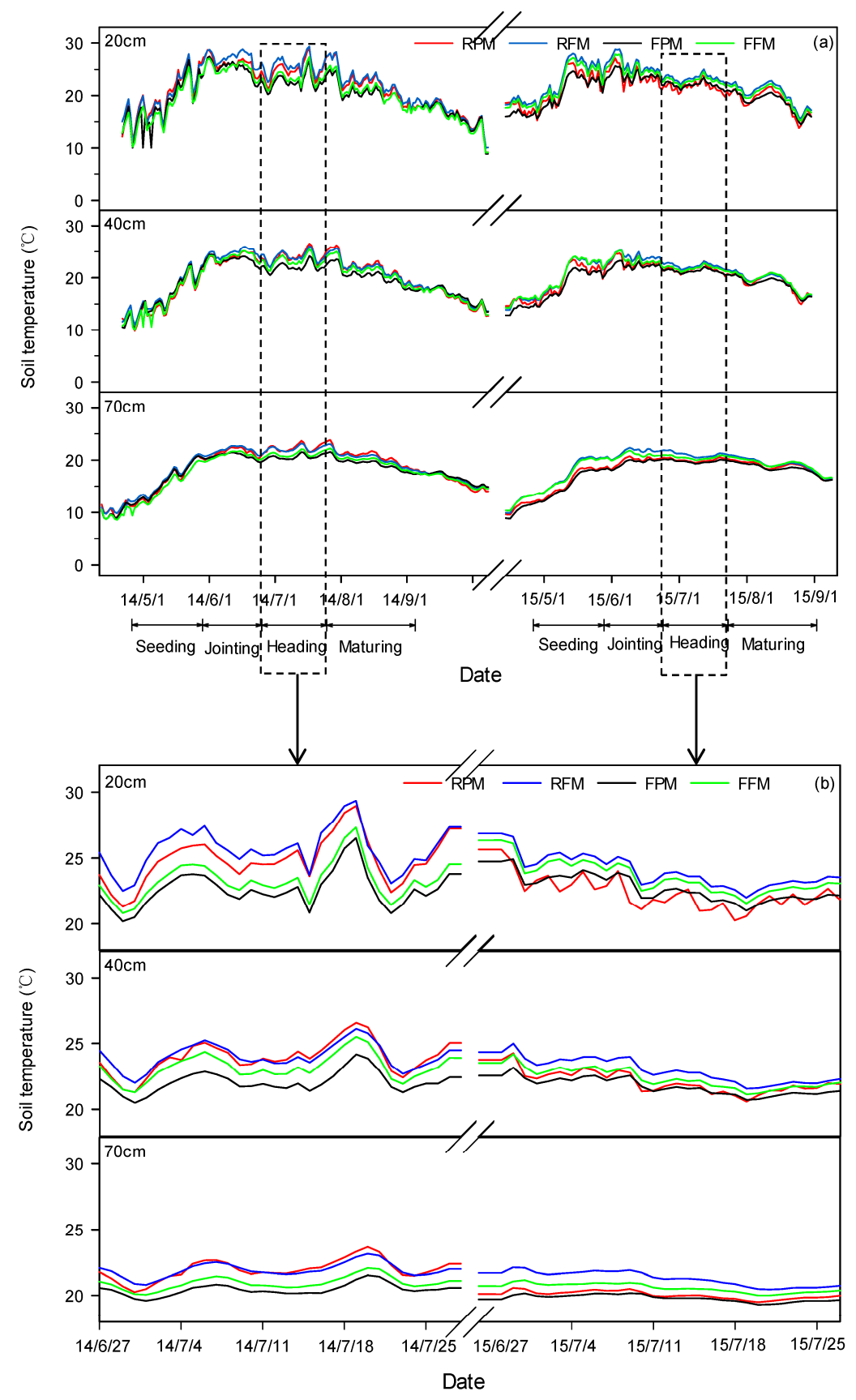

Figure 6. Daily average soil temperature of 0-70-cm layer in different treatments (a) during the growth period in 2014 and 2015 and (b) during the heading stage in 2015.

As the heading stage is the most productive period, soil thermal condition at this stage was selected for further analysis (Figure 6b). In 2014, when compared with RPM, RFM significantly 
increased the average temperature by $0.81{ }^{\circ} \mathrm{C}$ in the $20-\mathrm{cm}$ layer, however, there was no obvious difference between RPM and RFM in both the 40- and 70-cm layers. FFM had a greater effect on heat retention than FPM in the 0-70-cm layer, but there were no obvious differences in either the shallow or deep layers. In 2015, due to frequent irrigation, there was no difference between ridge tillage and flat tillage, while a significant difference was found between the partial and full plastic film mulch methods.

Variations of accumulated temperature in the 0-20-cm layer during the growth period in 2014 and 2015 are shown in Table 3. Soil temperature was increased and was maintained at higher levels with increasing air temperature and solar radiation in the jointing and heading stages in all four treatments (Figure 6a). Full plastic film mulch with ridge tillage increased average accumulated temperature by $1.31{ }^{\circ} \mathrm{C} /$ day and $0.90^{\circ} \mathrm{C} /$ day over flat tillage treatments during growth periods in 2014 and 2015, respectively. With flat tillage, full plastic film mulch increased average accumulated temperature by $0.59{ }^{\circ} \mathrm{C} /$ day and $0.97{ }^{\circ} \mathrm{C} /$ day more than partial plastic film mulch during growth periods in 2014 and 2015 , respectively.

Table 3. Accumulated soil temperature under different treatments during the growth period in 2014 and 2015.

\begin{tabular}{|c|c|c|c|c|c|}
\hline Treatment & $\begin{array}{c}\text { Seeding Stage } \\
\left({ }^{\circ} \mathrm{C}\right)\end{array}$ & $\begin{array}{c}\text { Jointing Stage } \\
\left({ }^{\circ} \mathrm{C}\right)\end{array}$ & $\begin{array}{c}\text { Heading Stage } \\
\left({ }^{\circ} \mathrm{C}\right)\end{array}$ & $\begin{array}{c}\text { Maturing Stage } \\
\left({ }^{\circ} \mathrm{C}\right)\end{array}$ & $\begin{array}{c}\text { Total Growth Stage } \\
\left({ }^{\circ} \mathrm{C}\right)\end{array}$ \\
\hline \multicolumn{6}{|c|}{2014} \\
\hline RPM & $672 \mathrm{~B}$ & $745 \mathrm{~F}$ & $808 \mathrm{H}$ & $778 \mathrm{~J}$ & $3003 \mathrm{~b}$ \\
\hline RFM & $691 \mathrm{~A}$ & $795 \mathrm{D}$ & $858 \mathrm{G}$ & 819 I & 3164 a \\
\hline FPM & $646 \mathrm{C}$ & $749 \mathrm{~F}$ & $770 \mathrm{E}$ & $750 \mathrm{~F}$ & 2915 c \\
\hline FFM & $645 \mathrm{C}$ & $761 \mathrm{E}$ & $807 \mathrm{H}$ & $778 \mathrm{~J}$ & 2992 b \\
\hline \multicolumn{6}{|c|}{2015} \\
\hline RPM & 493 B & $777 \mathrm{~F}$ & $827 \mathrm{D}$ & $833 \mathrm{D}$ & $2930 \mathrm{~b}$ \\
\hline RFM & $520 \mathrm{~A}$ & $835 \mathrm{D}$ & $865 \mathrm{H}$ & $880 \mathrm{I}$ & 3102 a \\
\hline FPM & $464 \mathrm{C}$ & $752 \mathrm{G}$ & $819 \mathrm{~J}$ & $822 \mathrm{~J}$ & $2857 \mathrm{c}$ \\
\hline FFM & 499 B & $804 \mathrm{E}$ & $832 \mathrm{D}$ & $849 \mathrm{D}$ & 2984 b \\
\hline
\end{tabular}

Notes: Effective accumulated temperature is the summed daily average temperature (above $10{ }^{\circ} \mathrm{C}$ ) during the growth period. RPM, ridges and furrows with only ridges mulched with white plastic film; RFM, ridges and furrows with full mulch; FPM, flatten tillage with $40 \mathrm{~cm}$ mulched with white plastic film; FFM, flatten tillage with full mulch. Different letters within the columns indicate differences in the least significant difference test at $p=0.05$; data are represented as means \pm standard error (S.E).

Figure 7 illustrates the variation and relationship of soil temperatures in different positions under film in the FFM treatment from 14 August to 6 September in 2014. The temperature in the center-position under the film reached the peak point together with the inter-position under film, while temperature in the edge-position under the film varied gently and was much lower than that in the other two positions. Regardless of position, the temperature under the film showed stronger diurnal variations than the bare area. 


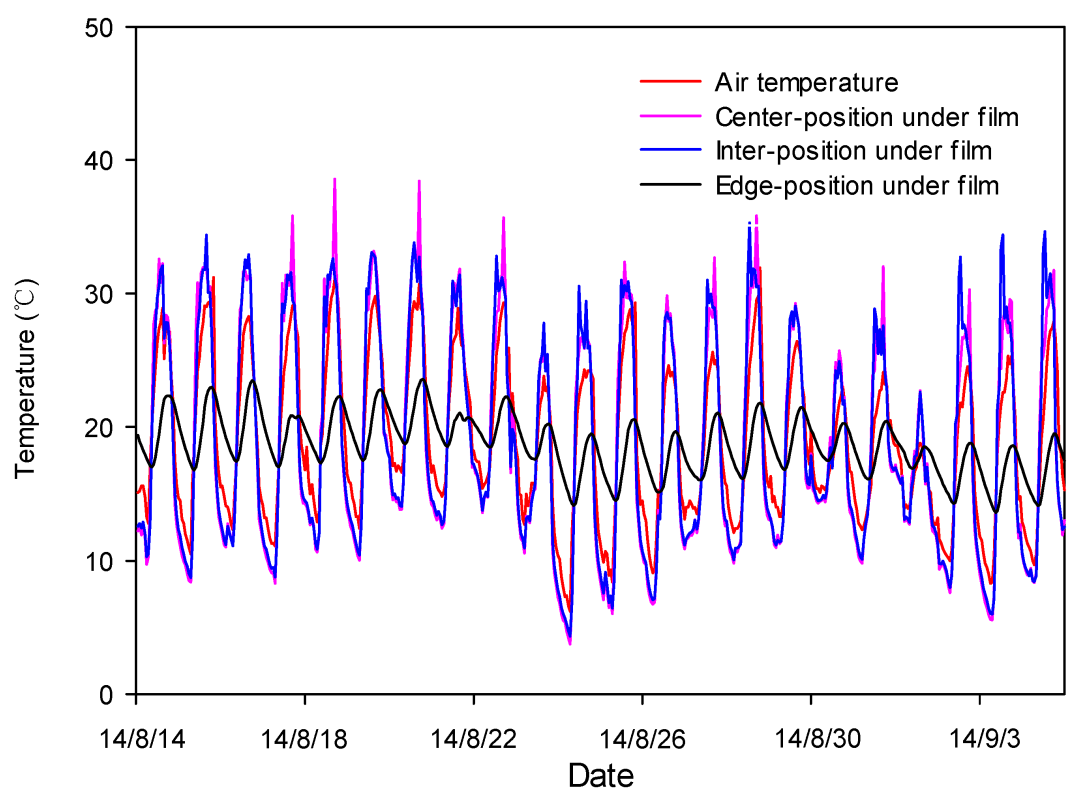

Figure 7. Daily changes of temperature in different positions under film, with the air temperature as a reference. Center-position under film (horizontal distance from the dripper is $0 \mathrm{~cm}$ ), inter-position under film (horizontal distance from the dripper is $20 \mathrm{~cm}$ ), edge-position under film (horizontal distance from the dripper is $50 \mathrm{~cm}$ ).

\subsection{Crop Growth and Yield}

There was a significant difference in the yield and WUE between full and partial plastic film mulches with the same tillage (Table 4). The highest yields, $15,583 \mathrm{~kg} \cdot \mathrm{ha}^{-1}$ in 2014 and 16,797 $\mathrm{kg} \cdot \mathrm{ha}^{-1}$ in 2015, were both in the RFM treatment. The yield in RFM was $42.6 \%, 26.1 \%$, and $9.1 \%$ higher in 2014, and 41.6\%, 36.0\% and 2.1\% higher in 2015 than RPM, FPM and FFM, respectively. No significant differences between RFM and FFM were found in the yield in 2014 and 2015. The ranking, from high to low, for row number and grain number per ear were always RFM, FFM, FPM, and RPM. The WUE in RFM and FFM was higher than RPM and FPM, and there was significant different between any two treatments. The trend of WUE was RFM > FFM > FPM > RPM. The value of WUE in RFM reached $40.21 \mathrm{~kg} \cdot \mathrm{ha}^{-1} \cdot \mathrm{mm}^{-1}$ and $39.10 \mathrm{~kg} \cdot \mathrm{ha}^{-1} \cdot \mathrm{mm}^{-1}$ in 2014 and 2015 respectively and was higher than other treatments.

The RFM had a significantly greater accumulation of biomass than FFM, FPM and RPM, indicating a positive combined effect of full plastic film mulch and ridge tillage (Figure 8a). Biomass accumulations were significantly different among all treatments from the late jointing stage and reached a peak in the early maturing stage, even though no further biomass accumulation was recorded during the last two weeks before harvest. Additionally, the LAI of maize in all treatments were generally lower in the jointing stage and peaked in the heading stage (Figure 8b). The average LAI in RFM were $12.7 \%, 22.9 \%$ and $34.7 \%$ in 2014 , and $0.08 \%, 14.5 \%$ and $19.2 \%$ in 2015 , higher than FFM, FPM, and RPM, respectively. Overall, the LAI in 2015 was significantly greater than in 2014 due to abundant precipitation and irrigation. The ranking, from high to low, for biomass and LAI were RFM, FFM, FPM and RPM. 
Table 4. Effect of treatments on the yield, its component factors, and water use efficiency (WUE) in 2014 and 2015.

\begin{tabular}{|c|c|c|c|c|c|c|c|c|c|}
\hline Treatment & $\begin{array}{c}\text { Number of Rows } \\
\text { per Ear }\end{array}$ & $\begin{array}{c}\text { Number of } \\
\text { Grains per Ear }\end{array}$ & $\begin{array}{l}\text { 1000 Grain } \\
\text { Weigh (g) }\end{array}$ & $\begin{array}{c}\text { Rate of } \\
\text { Fruiting }\end{array}$ & Yield $\left(\mathrm{kg} \cdot \mathrm{ha}^{-1}\right)$ & Rainfall (mm) & Irrigation (mm) & $\begin{array}{c}\text { Water Consumption } \\
(\mathrm{mm})\end{array}$ & $\begin{array}{c}\text { Water use Efficiency } \\
\left(\mathbf{k g} \cdot \mathbf{h a}^{-1} \cdot \mathrm{mm}^{-1}\right)\end{array}$ \\
\hline \multicolumn{10}{|c|}{2014} \\
\hline RPM & $16.21 \mathrm{~b}$ & $548.67 \mathrm{~b}$ & $355.08 \mathrm{c}$ & $0.91 \mathrm{~b}$ & $10,925 \mathrm{c}$ & 77 & 135 & $351.72 \mathrm{c}$ & $31.06 \mathrm{~d}$ \\
\hline RFM & $19.14 \mathrm{a}$ & $692.00 \mathrm{a}$ & $390.30 \mathrm{a}$ & $0.95 \mathrm{a}$ & $15,583 \mathrm{a}$ & 77 & 135 & $387.50 \mathrm{a}$ & $40.21 \mathrm{a}$ \\
\hline FPM & $16.47 \mathrm{~b}$ & $648.33 \mathrm{a}$ & $333.32 \mathrm{~d}$ & $0.91 \mathrm{~b}$ & $12,357 \mathrm{~b}$ & 77 & 135 & $365.42 \mathrm{~b}$ & $33.83 \mathrm{c}$ \\
\hline FFM & $18.33 \mathrm{a}$ & $678.00 \mathrm{a}$ & $375.07 \mathrm{~b}$ & $0.95 \mathrm{a}$ & $14,277 \mathrm{a}$ & 77 & 135 & $363.28 \mathrm{~b}$ & $39.29 b$ \\
\hline \multicolumn{10}{|c|}{2015} \\
\hline RPM & $21.22 \mathrm{~b}$ & $739.14 \mathrm{c}$ & $402.72 \mathrm{a}$ & $0.84 \mathrm{~d}$ & $11,857 \mathrm{~b}$ & 25 & 346 & $394.17 \mathrm{c}$ & $30.08 \mathrm{~d}$ \\
\hline RFM & $24.72 \mathrm{a}$ & 980.19 a & $369.67 \mathrm{~b}$ & $0.87 \mathrm{c}$ & $16,797 \mathrm{a}$ & 25 & 346 & $429.32 \mathrm{a}$ & $39.10 \mathrm{a}$ \\
\hline FPM & $21.38 \mathrm{~b}$ & $806.84 \mathrm{~b}$ & $338.73 \mathrm{c}$ & $0.90 \mathrm{~b}$ & $13,196 \mathrm{~b}$ & 25 & 346 & $411.65 \mathrm{~b}$ & $32.06 \mathrm{c}$ \\
\hline FFM & $23.06 \mathrm{a}$ & $837.83 \mathrm{~b}$ & $344.47 \mathrm{~d}$ & $0.91 \mathrm{a}$ & 16,445 a & 25 & 346 & $412.61 \mathrm{~b}$ & $38.29 \mathrm{~b}$ \\
\hline
\end{tabular}



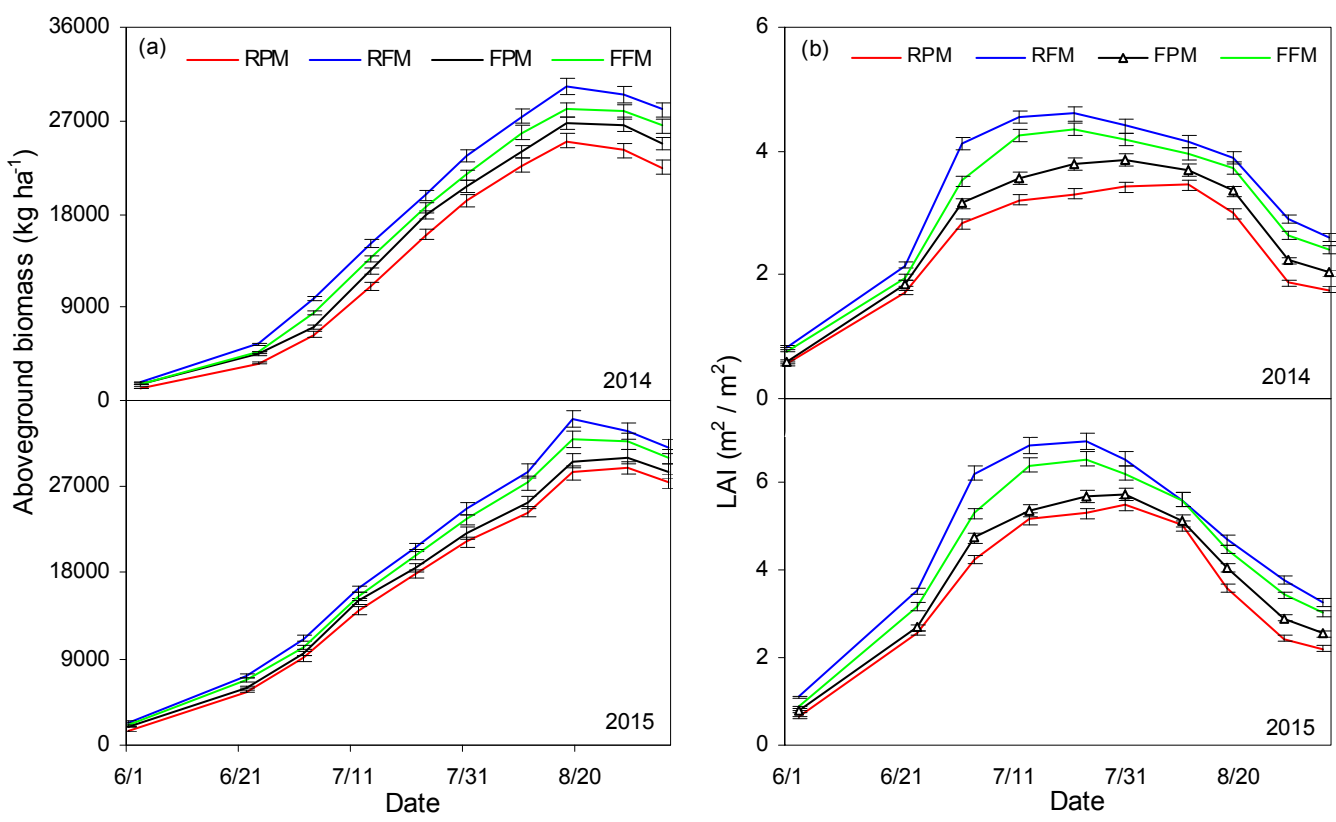

Figure 8. (a) Comparison of the aboveground biomass of individual maize plants in different treatments during the growth period in 2014 and 2015; (b) Leaf area index (LAI) of maize in different treatments during the growth period in 2014 and 2015.

\section{Discussion}

The yield and WUE of maize in full film mulching treatments, especially in the RFM treatment, was significantly higher than partial film mulched plots due to fewer evaporation losses. Although Zhang et al. reported that ridge tillage could promote soil nutrient accumulation and maintain moderate soil hydrothermal conditions, it did not significantly increase the maize yield and WUE in the present experiment. In contrast, ridge tillage combined with partial film mulch lead to more evaporation than with full film mulch, resulting in higher water consumption and lower WUE. The full plastic film mulch was more conducive in improving soil conditions affecting the yield (Table 4) and especially in reserving water in the profile (Figure 4a) than partial plastic film mulch. This demonstrates that full film mulching enhanced growth conditions by reducing evaporation, increasing infiltration, and accumulating soil thermal energy, and consequently improved grain filling and maturation, as also shown by others [31,32]. Wang et al. [28] reported ridge tillage and a full film mulching system in maize cropping efficiently enhanced water retention. Full plastic film mulch led to improvements in soil water content by reducing water loss through evaporation and promoting water infiltration to the subsoil in groundnut cropping [33]. Schwartz et al. [34] reported that mulching promoted soil water redistribution under the film after irrigation. Additionally, ridge tillage can increase the cross-sectional and surface area and the number of macropores of loose soil in the ridge, which allows for better infiltration and water conservation during both irrigation and rain and solar thermal collection [35]. However, ridge tillage, in the absence of mulching, also increased evaporation rates compared with flat tillage, especially during warm periods. Compared with partial plastic film mulch, full transparent plastic film mulch not only conserved solar energy through film effects, but also reduced water loss from bare soil, which was in accordance with the observations of Chen et al. [22] and Wang et al. [28].

In 2014 and 2015, during the seeding and jointing stages, the soil water content in 20-40-cm layer was higher in RFM than in other treatments while the lowest value was recorded in the RFM treatment. However, the situation was the opposite during heading and maturing stages at the 20-40 cm depth with the highest values in RFM and the lowest values in RFM. Jia et al. [36] reported that full film mulching could increase the infiltration rate, resulting in the promotion of water flow through plants and decreased evaporation and ET. However, the ET of RFM was significantly higher 
than that of RPM, FFM and FPM in 2014 and 2015. The reason for this was that the favorable soil thermal conditions in full film mulching treatments made plants grow vigorously, which led to more water consumption [36]. RFM resulted in higher soil temperature than in other treatments during the whole growth period. At the same time, the soil moisture in the $20-40 \mathrm{~cm}$ layer was lower than in other treatments during the heading and maturing stages. Therefore, ridge tillage mulched with full plastic film was beneficial to water accumulation and deposition to mitigate water shortages when the precipitation was little (2014), while it collected extra water in the ridge when rainfall or irrigation became rich (2015). The ridge mulched in the RPM treatment could collect and store water, and some water evaporated directly from the bare furrow, thereby reducing overall water storage under this treatment. In addition, the higher temperature under mulch as compared to the bare soil furrow causes water movement from ridge to the furrow where it can be evaporated. Compared with the RPM treatment, FFM effectively improved soil moisture through reducing evaporation but it was less effective in conserving water. The FPM treatment lost less water from the bare soil area than in the RPM plot.

Regardless of the layers and growth stages, soil water storage of RFM was higher than in the rest of the treatments and the full plastic mulch was better than partial plastic mulch in storing water. During the period from the seeding stage to jointing stage, soil water storage increases slightly due to less precipitation and gradually increased crop water consumption. Because of increasing precipitation and irrigation, soil water storage was supplied in every treatment during the heading stage. At this stage, RFM showed a greater water storage capacity than RPM. This implies that ridge tillage could be beneficial to increase soil water storage, to a certain extent through increasing rainwater retention and promoting infiltration, however, some soil water evaporated rapidly from un-mulched furrows under intense solar radiation, which is consistent with the results of previous research [37,38]. In contrast, during heading and maturing stage, soil water storage decreased in 0-70-cm layers of all treatments, especially in the $0-40-\mathrm{cm}$ layer of RFM and FFM. In the main root zone $(0-40 \mathrm{~cm})$, the difference in water storage between RFM and RPM was big while the opposite occurred between FFM and FPM during the maturing stage. The reasons for this notable phenomenon were: (1) compared with RPM, favorable hydrothermal conditions in RFM promoted crops to grow vigorously and further led to premature senescence; thus, higher water consumption was required to meet the requirement of crop growth; and (2) relatively slow growth of crops was recorded in FPM and thus growth period was also prolonged, therefore, crops needed more soil water to maintain growth. On the other hand, flat tillage could not effectively intercept rainfall and partial plastic film mulch further aggravated evaporation from un-mulched furrows [39,40]. Eventually, the soil water storage of FPM decreased comparatively more than that FFM.

Soil moisture and heat often have a synergistic effect on plant growth. High soil water content and temperature lead to shorter seed germination and emergence time [41]. Li et al. [31] found that moderate hydrothermal conditions under full film mulching can increase tiller numbers and prolong the phenostage, which contribute to a yield increase. Furthermore, favorable soil moisture and temperature conditions promote root development and absorption of water and nutrient resulting in high biomass accumulation and LAI.

In the present study, there was a reverse trend to the dynamic changing of soil moisture and soil temperature in tillage layer in both 2014 and 2015. Soil thermal conductivity and capacity highly rely on soil moisture and movement of soil water leads to thermal storage or transfer [42]. In addition, evaporation normally plays a crucial role in surface heat balance of dry area. High soil temperature caused strong evaporation and thus reduced soil moisture; in contrast, high soil water content could narrow soil temperature variation. RFM resulted in higher soil temperature and accumulated temperature than in other treatments, whereas the lowest values were recorded in FPM treatment. Ridge tillage provided better opportunity to capture solar energy, and was beneficial to transfer and accumulate heat to the deeper soil layers, thus augmenting and stabilizing the relative temperature of the subsoil [43]. However, most of surface soil heat was lost from bare ridges and furrows without 
full plastic film mulch (Figure 5a and Table 3). This is consistent with the results of [32,44]. On the other hand, flat tillage did not enhance soil surface temperature. Insulation of plastic film mulch with flat tillage was not obvious in our experiments. In the treatments where only a portion of the soil was mulched (RPM and FPM) soil temperatures were not as high as under fully mulched soil. Zhang et al. [37] reported that full transparent film mulching transmitted solar shortwave radiation and absorbed considerable heat during the daytime through film into soil surface, while limiting heat loss during the night by reducing longwave radiation from soil to the atmosphere.

In 2014, the soil temperature in RPM was higher than in FFM. However, it is opposite that higher soil temperature was recorded in FFM compared with RPM in 2015. The reason for this was that tillage had a significant effect on average temperature in 0-70-cm layer compared with mulching under drought conditions (2014). Conversely, mulching played a more important role in preserving thermal conditions than tillage under humid soil conditions (2015). Overall, ridge tillage efficiently increased soil surface temperature and enhanced thermal penetration in deeper soils, likely because the higher thermal conductivity caused by the higher moisture content. The ridge-tillage with full mulching (RFM) created the most favorable hydrothermal conditions for maize cultivation.

\section{Conclusions}

Full plastic film with drip irrigation efficiently promoted water infiltration and regulated the surface temperature resulting in favorable soil moisture conservation and evaporation inhibition. Compared with partial film mulching, full plastic film reduced evaporation and increased water availability. These effects were further enhanced with ridge tillage. In addition, full plastic film mulch had an insulation effect compared with partial plastic film mulch. Thus, thermal energy could be effectively transferred and stored in the tillage layer where it is essential for maize growth. Due to the increasing canopy density, soil temperature was mainly affected by solar radiation when maize was young and by atmospheric temperature with increasing growth. The opposite relationship was found between tillage layer temperature and water content. Overall, the ridge-tillage and full plastic film mulching was an effective soil water management system for maintaining suitable hydrothermal conditions for the growth and performance of irrigated maize, especially under low precipitation and high crop water consumption conditions.

Acknowledgments: This work was jointly supported by the National High Technology Research and Development Program of China (2013AA102904), the National Natural Science Foundation of China (41371234, 41371233, 51509238), and the "111" Project from the Ministry of Education and the State Administration of Foreign Experts Affairs (B12007). We are grateful to Markus Flury from Washington State University and Robert Lee Hill from Maryland University for the paper revision, and the staff of the Shuguang Experimental Station for their technical assistance.

Author Contributions: Zhijuan Qi, Hao Feng, Ying Zhao and Tibin Zhang conceived and designed the experiments; Zhijuan Qi and Lifeng Zhou performed the experiments; Zhijuan Qi and Ying Zhao analyzed the data; Hao Feng, Ying Zhao, Bingcheng Si and Tibin Zhang contributed reagents/materials/analysis tools; Zhijuan Qi wrote the paper.

Conflicts of Interest: The authors declare no conflict of interest.

\section{References}

1. Yang, Y.T.; Shang, S.H.; Jiang, L. Remote sensing temporal and spatial patterns of evapotranspiration and the responses to water management in a large irrigation district of North China. Agric. For. Meteorol. 2012, 164, 112-122. [CrossRef]

2. Liu, J.; Sun, S.; Wu, P.; Wang, Y.; Zhao, X. Inter-county virtual water flows of the Hetao irrigation district, China: A new perspective for water scarcity. J. Arid Environ. 2015, 119, 31-40. [CrossRef]

3. Wu, R.S.; Wu, R.F.; Hou, Q.; Zhao, H.Y.; Sun, X.L.; Jin, L.X.; Chao, L.M. Light and temperature indices during the seeding stage of spring maize in Hetao irrigation district, Inner Mongolia, China. Chin. J. Appl. Ecol. 2015, 26, 241-248. (In Chinese) 
4. $\quad \mathrm{Xu}, \mathrm{X}$.; Huang, G.; Qu, Z.; Pereira, L.S. Assessing the groundwater dynamics and impacts of water saving in the Hetao Irrigation District, Yellow River basin. Agric. Water Manag. 2010, 98, 301-313. [CrossRef]

5. Xue, Z.; Akae, T. Maximum surface temperature model to evaluate evaporation from a saline soil in arid area. Paddy Water Environ. 2012, 10, 153-159. [CrossRef]

6. Zhao, Y.; Pang, H.; Wang, J.; Huo, L.; Li, Y. Effects of straw mulch and buried straw on soil moisture and salinity in relation to sunflower growth and yield. Field Crops Res. 2014, 161, 16-25. [CrossRef]

7. Zhang, G.S.; Hu, X.B.; Zhang, X.X.; Li, J. Effects of plastic mulch and crop rotation on soil physical properties in rain-fed vegetable production in the mid-Yunnan plateau, China. Soil Tillage Res. 2015, 145, 111-117. [CrossRef]

8. Yasushi, M.; Atsushi, F.; Kazuto, Y. Installing artificial macropores in degraded soils to enhance vertical infiltration and increase soil carbon content. Prog. Earth Planet. Sci. 2014, 1, 30.

9. Zibilske, L.M.; Bradford, J.M.; Smart, J.R. Conservation tillage induced changes in organic carbon, total nitrogen and available phosphorus in a semi-arid alkaline subtropical soil. Soil Tillage Res. 2002, 66, 153-163. [CrossRef]

10. Chivenge, P.P.; Murwira, H.K.; Giller, K.E.; Mapfumo, P.; Six, J. Long-term impact of reduced tillage and residue management on soil carbon stabilization: Implications for conservation agriculture on contrasting soils. Soil Tillage Res. 2007, 94, 328-337. [CrossRef]

11. Zhang, S.; Li, Q.; Lu, Y.; Sun, X.; Jia, S.; Zhang, X.; Liang, W. Conservation tillage positively influences the microflora and microfauna in the black soil of Northeast China. Soil Tillage Res. 2015, 149, 46-52. [CrossRef]

12. Chakraboyty, D.; Nagarajan, S.; Aggarwal, P.; Gupta, V.K.; Tomar, R.K.; Garg, R.N.; Sahoo, R.N.; Sarkar, A.; Chopra, U.K.; Sarma, K.S.S.; et al. Effect of mulching on soil and plant water status, and the growth and yield of wheat (Triticum aestivum L.) in a semi-arid environment. Agric. Water Manag. 2008, 95, 1323-1334. [CrossRef]

13. Chakraborty, D.; Garg, R.N.; Tomar, R.K.; Singh, R.; Sharma, S.K.; Singh, R.K.; Trivedi, S.M.; Mittal, R.B.; Sharma, P.K.; Kamble, K.H. Synthetic and organic mulching and nitrogen effect on winter wheat (Triticum aestivum L.) in a semi-arid environment. Agric. Water Manag. 2010, 97, 738-748. [CrossRef]

14. Zhou, L.M.; Li, F.M.; Jin, S.L.; Song, Y.J. How two ridges and the furrow mulched with plastic film affect soil water, soil temperature and yield of maize on the semiarid Loess Plateau of China. Field Crops Res. 2009, 113, 41-47. [CrossRef]

15. Lal, R. Soil temperature, Soil moisture and maize yield from mulched and unmulched tropical soils. Plant Soil 1974, 40, 129-143. [CrossRef]

16. Gill, K.S.; Gajri, P.R.; Chaudhary, M.R.; Singh, B. Tillage, mulch and irrigation effects on corn (Zea mays L.) in relation to evaporative demand. Soil Tillage Res. 1996, 39, 213-227. [CrossRef]

17. Gan, Y.T.; Siddique, K.H.M.; Turner, N.C.; Li, X.G.; Niu, J.Y.; Yang, C.; Liu, L.P.; Chai, Q. Ridge-Furrow Mulching Systems-An Innovative Technique for Boosting Crop Productivity in Semiarid Rain-Fed Environments. In Advances in Agronomy; Sparks, D.L., Ed.; Elsevier: Amsterdam, The Netherlands, 2013; Volume 118, pp. 429-476.

18. Mackay, A.D.; Barber, S.A. Soil-temperature effects on root-growth and phosphorus uptake by corn. Soil Sci. Soc. Am. J. 1984, 48, 818-823. [CrossRef]

19. Kirschbaum, M.U.F. The temperature-dependence of soil organic-matter decomposition, and the effect of global warming on soil organic C storage. Soil Biol. Biochem. 1995, 27, 753-760. [CrossRef]

20. Kodesova, R.; Fer, M.; Klement, A.; Nikodem, A.; Tepla, D.; Neuberger, P.; Bures, P. Impact of various surface covers on water and thermal regime of Technosol. J. Hydrol. 2014, 519, 2272-2288. [CrossRef]

21. Camp, C.R. Subsurface drip irrigation: A review. Trans. ASAE 1998, 41, 1353-1367. [CrossRef]

22. Chen, Y.L.; Liu, T.; Tian, X.H.; Wang, X.F.; Li, M.; Wang, S.X.; Wang, Z.H. Effects of plastic film combined with straw mulch on grain yield and water use efficiency of winter wheat in Loess Plateau. Field Crops Res. 2015, 172, 53-58. [CrossRef]

23. Xu, J.; Li, C.F.; Liu, H.T.; Zhou, P.L.; Tao, Z.Q.; Wang, P.; Meng, Q.F.; Zhao, M. The Effects of Plastic film mulching on maize growth and water use in dry and rainy years in Northeast China. PLOS ONE 2015, 10, e0125781. [CrossRef] [PubMed]

24. Zhang, S.; Lovdahl, L.; Grip, H.; Tong, Y.; Yang, X.; Wang, Q. Effects of mulching and catch cropping on soil temperature, soil moisture and wheat yield on the Loess Plateau of China. Soil Tillage Res. 2009, 102, 78-86. [CrossRef] 
25. Burt, C.M.; Isbell, B. Leaching of accumulated soil salinity under drip irrigation. Trans. ASAE 2005, 48, 2115-2121. [CrossRef]

26. Selim, T.; Bouksila, F.; Berndtsson, R.; Persson, M. Soil Water and Salinity Distribution under Different Treatments of Drip Irrigation. Soil Sci. Soc. Am. J. 2013, 77, 1144-1156. [CrossRef]

27. Tolk, J.A.; Howell, T.A.; Evett, S.R. Effect of mulch, irrigation, and soil type on water use and yield of maize. Soil Tillage Res. 1999, 50, 137-147. [CrossRef]

28. Wang, Y.P.; Li, X.G.; Zhu, J.; Fan, C.Y.; Kong, X.J.; Turner, N.C.; Siddique, K.H.M.; Li, F.M. Multi-site assessment of the effects of plastic-film mulch on dryland maize productivity in semiarid areas in China. Agric. For. Meteorol. 2016, 220, 160-169. [CrossRef]

29. Sepaskhah, A.R.; Kanooni, A.; Ghasemi, M.M. Estimating water table contributions to corn and sorghum water use. Agric. Water Manag. 2003, 58, 67-79. [CrossRef]

30. Gao, Y.; Wu, P.T.; Zhao, X.N.; Wang, Z.K. Growth, yield, and nitrogen use in the wheat/maize intercropping system in an arid region of northwestern China. Field Crops Res. 2014, 167, 19-30. [CrossRef]

31. Li, F.M.; Guo, A.H.; Wei, H. Effects of clear plastic film mulch on yield of spring wheat. Field Crops. Res. 1999, 63, 79-86. [CrossRef]

32. Ramakrishna, A.; Tam, H.M.; Wani, S.P.; Long, T.D. Effect of mulch on soil temperature, moisture, weed infestation and yield of groundnut in northern Vietnam. Field Crops Res. 2006, 95, 115-125. [CrossRef]

33. Ghosh, P.K.; Dayal, D.; Bandyopadhyay, K.K.; Mohanty, K. Evaluation of straw and polythene mulch for enhancing productivity of irrigated summer groundnut. Field Crops Res. 2006, 99, 76-86. [CrossRef]

34. Schwartz, R.C.; Baumhardt, R.L.; Evett, S.R. Tillage effects on soil water redistribution and bare soil evaporation throughout a season. Soil Tillage Res. 2010, 110, 221-229. [CrossRef]

35. Vucajnk, F.; Vidrih, M.; Bernik, R. Physical and mechanical properties of soil for ridge formation, ridge geometry and yield in new planting and ridge formation methods of potato production. Ir. J. Agric. Food Res. 2012, 51, 13-31.

36. Jia, Y.; Li, F.M.; Wang, X.L.; Yang, S.M. Soil water and alfalfa yields as affected by alternating ridges and furrows in rainfall harvest in a semiarid environment. Field Crop Res. 2006, 97, 167-175. [CrossRef]

37. Zhang, S.L.; Li, P.R.; Yang, X.Y.; Wang, Z.H.; Chen, X.P. Effects of tillage and plastic mulch on soil water, growth and yield of spring-sown maize. Soil Tillage Res. 2011, 112, 92-97. [CrossRef]

38. Chen, S.Y.; Zhang, X.Y.; Pei, D.; Sun, H.Y.; Chen, S.L. Effects of straw mulching on soil temperature, evaporation and yield of winter wheat: Field experiments on the North China Plain. Ann. Appl. Biol. 2007, 150, 261-268. [CrossRef]

39. Benjamin, J.G. Tillage effects on near-surface soil hydraulic-properties. Soil Tillage Res. 1993, 26, $277-288$. [CrossRef]

40. Crittenden, S.J.; Poot, N.; Heinen, M.; van Balen, D.J.M.; Pulleman, M.M. Soil physical quality in contrasting tillage systems in organic and conventional farming. Soil Tillage Res. 2015, 154, 136-144. [CrossRef]

41. Gelmond, H. Problems in crop seed germination. In Crop Physiology; Gupta, U.S., Ed.; Oxford and IBH: New Delhi, India, 1978; pp. 7-15.

42. Janssen, H.; Carmeliet, J.; Hens, H. The influence of soil moisture transfer on building heat loss via the ground. Build. Environ. 2004, 39, 825-836. [CrossRef]

43. Krause, U.; Koch, H.J.; Maerlaender, B. Soil properties effecting yield formation in sugar beet under ridge and flat cultivation. Eur. J. Agron. 2009, 31, 20-28. [CrossRef]

44. Graefe, J. Simulation of soil heating in ridges partly covered with plastic mulch, part I: Energy balance model. Biosyst. Eng. 2005, 92, 391-407. [CrossRef]

(C) 2016 by the authors; licensee MDPI, Basel, Switzerland. This article is an open access article distributed under the terms and conditions of the Creative Commons Attribution (CC-BY) license (http://creativecommons.org/licenses/by/4.0/). 